\title{
EFFECT OF STRETCH ON MUSCLE PAIN REDUCTION IN CLEANING SERVANTS AT Dr. TJITROWARDOJO HOSPITAL, PURWOREJO, CENTRAL JAVA
}

\author{
Dewi Septianawati'), Yamtana'), Abdul Hadi Kadarusno') \\ 1)Dr. Tjitrowardojo Purworejo Hospital, Purworejo, Central Java \\ 2)Department of Environmental Health, School of Health Polytechnics, \\ Ministry of Health, Yogyakarta
}

\begin{abstract}
Background: Musculoskeletal Disorder (MSD) is complaints on parts of the skeletal muscle that are felt by a person ranging from mild to severe complaints. The cleaning servants at Dr. Tjitrowardojo Hospital are exposed to hazard directly and indirectly, which may affect their health. This study aimed to determine the effect of stretching on muscle pain reduction in cleaning servants at Dr. Tjitrowardojo Hospital, Purworejo, Central Java.

Subjects and Method: This was a quasi-experiment pretest-posttest design conducted at Dr. Tjitrowardojo Hospital, Purworejo, Central Java. A sample of 32 cleaning servants were selected at random for this study. The dependent variable was muscle pain. The independent variable was muscle strecthing. The pain data was measured by Nordic Body Map questionnaire. Stretching exercise was measured by observation sheet. Data was analyzed by bivariate analysis by Wilcoxon Rank Test.

Results: Musculoskeletal Disorder (MSDs) complaints were lower after intervention group than before, and it was statistically significant ( $\mathrm{p}<0.001)$.

Conclusion: Muscle stretching was effective in reducing pain among cleaning servants at Dr. Tjitrowardojo Hospital.
\end{abstract}

Keywords: stretching, musculosceletal disorders, cleaning servant, hospital.

\section{Correspondence:}

Yamtana. Department of Environmental Health, School of Health Polytechnics, Ministry of Health, Yogyakarta. Email: yamtanakesmas@yahoo.co.id. Mobile: 081344782344 .

The $6^{\text {th }}$ International Conference on Public Health

Best Western Premier Hotel, Solo, Indonesia, October 23-24, 2019 | 353

https://doi.org/10.26911/the6thicph.05.18 